\title{
Optimization Modelling of Conjunctive Use of the Irrigation Water Resources for Agricultural Sustainability
}

\author{
Deepak Kumar ${ }^{1 *}$ and M. K. Tiwari ${ }^{2}$ \\ ${ }^{1}$ Department of Soil and Water Conservation Engineering, CAET, \\ JAU, Junagadh, Gujarat-362001, India \\ ${ }^{2}$ Department of Irrigation and Drainage Engineering, CAET, \\ AAU, Godhra, Gujarat-389001, India \\ *Corresponding author
}

\section{Keywords \\ Canal command, Crop water requirement, Linear programming, Optimization, Net profit}

\section{Article Info}

Accepted: 10 April 2020 Available Online: 10 May 2020

\section{A B S T R A C T}

Agriculture is the base to all strategies for planned socio-economic development of most of the countries. Studies have shown that $40 \%$ of food production is achieved from $17 \%$ of the irrigated areas in the world. As it is not possible to expand agricultural area and possibility of increasing production per unit area of available land and water resources are minimal, it is the need of time that surface and groundwater should be used in conjunction for optimal utilization of water resources. It is imperative to optimize the good quality available water and land resources to achieve maximum agricultural revenues. The optimal allocation of resources can be achieved by using an optimization model. Linear programming technique is presented to arrive at an optimal allocation of resources for the maximization of farm income. The study area taken in this study is commanded by the 23-R, distributary which is a part of the Panam irrigation project. The present study was undertaken for optimizing the cropping pattern under different scenarios including available surface and groundwater resources for maximizing the net return in the study area using linear programming optimization technique. In this study optimum cropping pattern was proposed for maximum net return for the major crops in the distributaries. Besides farmers affinity design and existing canal water supply rate and different scenarios of groundwater and surface water were considered. It is found in this study that by using the optimization techniques the net return of the major crops such as Wheat, Maize and Fodder can be increased by $4.8,6.7$ and 11.7 times respectively compared to the existing cropping pattern in the canal distributary. 


\section{Introduction}

In India $91.6 \%$ of the water is used for irrigation purpose as compared to $84 \%$ in overall Asia \& $71 \%$ in the world (1). The ultimate irrigation potential of India has been estimated as 140 Mha. Out of this, 76 Mha would come from surface water and 64 Mha from ground water resources (1). Groundwater represents the second-most abundantly available freshwater resources and constitutes about $30 \%$ of fresh water resources of the globe (2). Conjunctive use of surface water and groundwater combines the advantage of groundwater with surface water system and serves both a remedial and corrective measures for efficient management. Therefore, it is always desired that surface and groundwater should be used in conjunction for optimal utilization of water resources and minimization of delirious effects of isolated development. Moreover, the climate change impacts and deteriorating water quality due to contamination of different water sources, further limit the water availability (3). Therefore, it is imperative to optimize the good quality available water and land resources to achieve maximum agricultural revenues (4). Therefore, the present study was undertaken for optimal cropping pattern for available surface and groundwater resources in the Panam canal command area using linear programming optimization technique.

\section{Materials and Methods}

\section{Study area}

\section{Location}

The study area is located in Sahera village, which comes under the periphery of Panchmahal district in Gujarat state. It is commanded by the 23-R, distributary which is a part of the Panam irrigation project. The
Cultural Command Area (CCA) of 23-R, is 2070 ha. The 23-R distributary is located at around $22.95^{\circ} \mathrm{N}$ latitude and $73.63^{\circ}$ East longitude near Sahera City. A Location Map of study Area is presented in Fig.1.

\section{Climate}

The study area experiences the similar climatic condition as that of the Panam basin which contains two climatic regions, the northern part of the basin comprises subtropical wet climate (generally basin area occupied by Rajasthan). The major part of basin comprises tropical wet climate, caused mainly due to existence of Vindhyas \& the Western Ghats.

The project area experiences minimum temperature of $4.8^{\circ} \mathrm{C}$ in January and maximum temperature $43.5^{\circ} \mathrm{C}$ in May. Average annual rainfall in the area is $940 \mathrm{~mm}$. About $80 \%$ of the rainfall occurs during July and August. On an average there are only 35 to 40 rainy-days per annum, which mostly fall during the period mid - June to midSeptember. There are frequent dry spells occurring over years.

\section{Major crops}

The major crops grown in the study area are Paddy, Castor, Jowar/Bajra/Maize and Wheat. Paddy is the major crop cultivated during Kharif season and wheat is the major crop grown in Rabi season.

\section{Soil}

The soils of the study area are medium textured. Depending upon the land types, physical as well as chemical properties of soil vary markedly. The soils are slightly alkaline in nature with $\mathrm{pH}$ value ranging between 7.9 and 8.2. 


\section{Irrigation}

In the study area canal irrigation system is mostly in use. Irrigation water is diverted from the Panam reservoir through a network of canals including the Panam main canal, $23 / \mathrm{R}$ distributary and it's minors, water courses and field channels etc. Irrigation details of $23 / \mathrm{R}$ distributary are given in following table 3 .

\section{Model description}

A linear programming model was formulated that allocates available land and water resources in order to maximize net farm income from the command area. The model consists of a linear objective function, a set of linear constraints, and a set of non-negativity constraints. The model description follows.

\section{Objective function}

The objective function of the model is given as:

Max: $Z=\sum_{\mathrm{i}=1}^{\mathrm{n}} N R_{\mathrm{i}} A_{\mathrm{i}}$

Where, $\mathrm{i}=$ Number of different crops grown in canal command area i.e. ( $\mathrm{i}=1$ for Wheat, $\mathrm{i}=2$ for Maize, $i=3$ for fodder crops, $i=4$ for other crops, $i=5$ for Castor and $i=6$ for cotton).

$\mathrm{NRi}=$ Net return of ith crop in Rs/ha.

$\mathrm{Ai}=$ Crop Area of ith crop in ha.

$\mathrm{n}=$ Total number of crops grown in canal command

$\mathrm{Z}=$ Net return from the command area in Rs.

\section{Model constraints}

The objective function maximization is subject to the following constraints:

\section{Land area}

Land allocated to various crops during the
Rabi seasons must not exceed CCA of Distributary.

$\sum_{\mathrm{i}=1}^{\mathrm{n}} A_{\mathrm{i}} \leq C C A_{*}$

Where,

$\mathrm{CCA}=$ Culturable command area of distributary in ha.

\section{Irrigation requirement}

The irrigation requirements of all the crops must be fully satisfied during Rabi seasons from the available canal water and groundwater resources.

$\sum_{i=1}^{\mathrm{n}} G I R_{\mathrm{i}} A_{\mathrm{i}} \leq V G W+V C W$

Where,

GIRi = Gross irrigation requirement of ithcrop (in ha-m).

$\mathrm{VGW}=$ Volume of ground water in ha-m.

$\mathrm{VCW}=$ Volume of canal water in ha-m.

\section{Canal water supply}

The availability of canal water for irrigation is limited. So, canal water allocation must not exceed the available canal water in a Rabi season.

$V C W \leq A V C W$

Where,

$\mathrm{AVCW}=$ Volume of available canal water in ha-m.

$\mathrm{VCW}=$ Volume of canal water in ha-m.

\section{Groundwater balance}

The water balance components of the aquifer are given as:

$\sum_{i=1}^{n} V G W_{i}-R C L \sum_{i=1}^{W} V C W_{i}-R A L \sum_{i=1}^{n}\left(V G W_{i}+V C W_{i}\right)-R R R \sum_{i=1}^{n} R R_{i} A_{i} \geq G W M$ 
Where,

VGWi = Volume of ground water used in ith crop in ha-m.

RCL $=$ Recharge factor for conveyance losses of canal water (fraction) $=0.30$

VCWi $=$ Volume of canal water used in ith crop in ha-m.

$\mathrm{RAL}=$ Recharge factor for irrigation application losses (fraction) $=0.41$

$\mathrm{RRF}=$ Recharge factor for rainfall (fraction) $=0.20$

$\mathrm{RFi}=$ Rainfall amount during ith crop (in $\mathrm{mm})$.

$\mathrm{Ai}=$ Crop area of ith crop in ha.

The recharge factor is the fraction of the water loss from the irrigation system that joins the ground water.

\section{Crop area}

Keeping in view the local food requirement, socio-economic issues, and prevailing cropping practices, a lower and upper limit of area under different crops was considered in the optimization model as constraint.

$\mu_{i}^{\min } T A_{\mathrm{i}} \leq A_{\mathrm{i}} \leq \mu_{\mathrm{i}}^{\max } T A_{\mathrm{i}}$

Where,

$\mu_{i}^{\min }=$ fraction to which the existing area of crop i can be decreased.

$\mu_{i}^{\max }=$ fraction to which the existing area of crop i can be increased.

$\mathrm{TA}_{\mathrm{i}}=$ Existing area of crop $\mathrm{i}$ in ha.

$\mathrm{Ai}=$ Crop area of ith crop in ha.

\section{Affinity of the people to that crop}

While deciding the maximum and minimum allowable area under different crops, the survey was conducted in command area of 23/R for taking information from farmers about affinity of people towards different crops. From survey report maximum and minimum allowable crop area constraints were decided and crop area was optimized for maximization of net profit against different constraints.

From survey report following constraints were decided of different distributaries

In farmer's affinity survey it was found that in different scenario of canal running days the farmer's affinity toward different crops was changing even in same distributary.

Non-negativity constraints

$A i \geq 0 ; V C W \geq 0 ; V G W \geq 0 ;$

Different scenario of crop area optimization

Considering the objective of net return optimization, the area allocated to different crop activities was optimized under different scenario for various level of water availability i.e. number of canal running days.

Scenario I. Existing running days at full supply

Scenario II.60 running days at full supply Scenario III. 90 running days at full supply Scenario IV.120 running days at full supply, Scenario V. Existing running days at full supply with ground water,

Scenario VI. 60 running days at full supply with ground water,

Scenario VII. 90 running days at full supply with ground water

Scenario VIII. 120 running days at full supply with ground water.

\section{Model inputs determination}

The model inputs include determination of the crop yields with different qualities of irrigation water (5), groundwater mining allowance, permissible cost of cultivation, 
irrigation requirement of crops, and net return of crops. The cost of land is not taken into account in calculating the cost of cultivation because it is farmers' own land. Description of different input parameters follows:

\section{Irrigation requirement}

The water requirement of crops was computed by the method recommended by (6). A reference crop evapotranspiration (ETo) was first calculated from the weather data using (7) as:

$\mathrm{ET}_{\mathrm{O}}=0.0023 \times \mathrm{R}_{\mathrm{a}} \times\left(\mathrm{T}_{\mathrm{avg}}+17.8\right) \times\left(\mathrm{T}_{\text {max }}-\right.$ $\left.\mathrm{T}_{\min }\right)^{0.5}$

Where,

$\mathrm{ET}_{\mathrm{O}}=$ Reference crop evapotranspiration $(\mathrm{mm} / \mathrm{d})$

$\mathrm{Ra}=$ Extraterrestrial solar radiation $(\mathrm{mm} / \mathrm{d})$

$\mathrm{T}_{\text {avg }}=$ Daily mean air temperature $\left({ }^{\circ} \mathrm{C}\right)$

Tmax = Daily maximum air temperature $\left({ }^{\circ} \mathrm{C}\right)$

Tmin $=$ Daily minimum air temperature $\left({ }^{\circ} \mathrm{C}\right)$

From the ETo values, the potential crop evapotranspiration (ETc) was calculated for each crop by using suitable crop coefficients (Kc) (Allen et al., 1998) using the following relationship:

$\mathrm{ET}_{\mathrm{C}}=\mathrm{ET}_{\mathrm{O}} \times \mathrm{K}_{\mathrm{C}}$

Seasonal effective rainfall (Reff) was determined by FAO method (8). According to this method the Reff was estimated from daily rainfall $(\mathrm{R})$ as:

$\mathrm{R}_{\text {eff }}(\mathrm{t})=0.7 \mathrm{R}(\mathrm{t})$, for non-rice crops

$\mathrm{R}_{\mathrm{eff}}(\mathrm{t})=0.8 \mathrm{R}(\mathrm{t})$, for rice

The gross irrigation requirement (GIR) of each crop during both the seasons was calculated by considering seasonal Reff data as:

$\mathrm{GIR}=\frac{\frac{E T_{C}-R_{\text {eff }}}{E_{P}}}{\mathrm{~S}}+\mathrm{SPR}-\mathrm{SMC}-\mathrm{GWC}$

Where,

$\mathrm{E}_{\mathrm{p}}=$ Overall project efficiency;

SPR = special purpose water requirement (mm) $(200 \mathrm{~mm}$ for paddy and $70 \mathrm{~mm}$ for other crops)

$S M C=$ soil moisture contribution $(\mathrm{mm})$

$G W C=$ contribution from groundwater $(\mathrm{mm})$

$\mathrm{E}_{\mathrm{P}}$ was computed as

$\mathrm{E}_{\mathrm{p}}=\mathrm{E}_{\mathrm{b}} \times \mathrm{E}_{\mathrm{a}}$

Where,

$\mathrm{E}_{\mathrm{p}}=$ Overall project efficiency

$\mathrm{E}_{\mathrm{b}}=$ Field channel conveyance efficiency (fraction)

$\mathrm{Ea}=$ application efficiency (fraction)

Based on the information available for the similar soil and agro-hydro- climatic conditions, the values of $\mathrm{E}_{\mathrm{b}}$ and $\mathrm{E}_{\mathrm{a}}$ were taken as 0.70 and 0.59 , respectively (9).

\section{Production cost of crops}

The production cost of various crops, excluding the cost of irrigation water, was collected from the Department of Agricultural Economics of B. A. College of Agriculture, Anand Agricultural University, Anand, Gujarat and office of the Executive Engineer, Panam Irrigation Subdivision, Project circle, Godhara. The minimum support price, the lowest price government fixes for a crop procurement, of different crops was taken as the market price of specific crops. The net revenue of individual crops with different qualities of irrigation water was determined by the production functions and prices of grain and its byproducts. 


\section{Permissible ground water mining}

Permissible annual groundwater mining allowance of the aquifer (GWM) was calculated as:

$\mathrm{GWM}=\Delta \mathrm{h} \times \mathrm{A} \times{ }^{S_{y}} \times 10^{-1}$

Where,

$\Delta \mathrm{h}=$ Average annual water table fluctuations (m)

$\mathrm{A}=$ Area under considerations (ha)

$\mathrm{S}_{\mathrm{y}}=$ Specific yield of the aquifer (fraction).

\section{Canal running days}

Table.12: Running Days with Break Period of 23-R Distributary for Year 2015-16

\section{Results and Discussion}

\section{Existing status of the command area}

The existing cropping pattern in the command area of 23-R distributary includes Wheat, Maize and Fodder crops in Rabi Season. The area under these crops is shown in Fig. 3. As per existing cropping pattern the maximum area during Rabi season is put under Wheat (234.72 ha) and minimum under Fodder (36.3 ha). The actual achievement in the net benefit was Rs. 89.86 lakh.

\section{Conjunctive use plan by optimization}

\section{Optimal irrigation plan for command area}

Under existing canal running days at design supply rate

The optimized cropping pattern in the command area of 23-R distributary includes Wheat, Maize fodder and other in Rabi Season. The area under these crops is shown in Fig. 4. As per optimized cropping pattern under existing canal running days at design supply rate, the maximum area during Rabi season is put under Wheat (1035 ha) and minimum under Fodder (207 ha). The potential achievement in the net benefit was Rs. 629.8 lakh.

\section{0 canal running days at design supply rate}

The optimized cropping pattern in the command area of 23-R distributary include Wheat, Maize, Fodder and Other in Rabi Season. The Area under these crops is shown in fig. 5. As per optimized Cropping pattern under 60 canal running days at design supply rate, the maximum area during Rabi season is put under Wheat $(621 \mathrm{ha})$ and minimum under Other $(19$ ha). The potential achievement in the net benefit was Rs. 352.93 lakh.

\section{0 canal running days at design supply rate}

The optimized cropping pattern in the command area of 23-R distributary include Wheat, Maize, Fodder and Other in Rabi Season. The Area under these crops is shown in Fig. 6. As per optimized cropping pattern under 90 canal running days at design supply rate, the maximum area during Rabi season is put under Wheat (1035 ha) and minimum under Other (103.5 ha). The potential achievement in the net benefit was Rs. 575.8 lakh.

\section{0 canal running days at design supply rate}

The optimized cropping pattern in the command area of 23-R distributary include Wheat, Maize, Fodder and Other in Rabi Season. The area under these crops is shown in Fig. 7. As per optimized cropping pattern under 120 canal running days at design supply rate, the maximum area during Rabi season is put under Wheat (1035 ha) and minimum under Fodder (207 ha). The potential achievement in the net benefit was Rs. 629.8 lakh. 
Existing canal running days at design supply rate with ground water

The optimized cropping pattern in the command area of 23-R distributary include Wheat, Maize, Fodder and other in Rabi season. The area under these crops is shown in Fig. 8. As per optimized cropping pattern under existing canal running days at design supply rate with ground water, the maximum area during Rabi season is put under Wheat $(1138.5 \mathrm{ha})$ and minimum under other $(0.5$ ha). The potential achievement in the net benefit was Rs. 530.02 lakh.

60 canal running days at design supply rate with ground water

The optimized cropping pattern in the command area of 23-R distributary includes Wheat, Maize, Fodder and Other in Rabi Season. The Area under these crops is shown in fig. 9. As per optimized Cropping pattern under 60 canal running days at design supply rate with ground water, the maximum area during Rabi season is put under Wheat (931.5 ha) and minimum under Other (29.5 ha). The potential achievement in the net benefit was Rs. 379.3 lakh.
90 canal running days at design supply rate with ground water

The Optimized cropping pattern in the command area of 23-R distributary include Wheat, Maize, Fodder and Other in Rabi Season. The Area under these crops is shown in fig. 10. As per optimized Cropping pattern under 90 canal running days at design supply rate with ground water, the maximum area during Rabi season is put under Wheat (1138 ha) and minimum under Other (1 ha). The potential achievement in the net benefit was Rs. 500.58 lakh.

\section{0 canal running days at design supply rate with ground water}

The Optimized cropping pattern in the command area of 23-R distributary includes Wheat, Maize and Fodder in Rabi Season. The Area under these crops is shown in fig. 11. As per optimized Cropping pattern under 120 canal running days at design supply rate with ground water, the maximum area during Rabi season is put under Wheat (1138.5 ha) and minimum under Fodder (310.5 ha). The potential achievement in the net benefit was Rs. 500.13 lakh.

Table.1 Areas (ha) under Major Crops under 23/R Distributary during 2014-2016

\begin{tabular}{|l|c|c|c|c|}
\hline \multirow{4}{*}{ Crop } & \multicolumn{2}{|c|}{ 2014-15 } & \multicolumn{2}{c|}{ 2015-16 } \\
\cline { 2 - 5 } & Kharif & Rabi & Kharif & Rabi \\
\hline Castor & - & - & - & - \\
\hline Wheat & - & 236.2 & - & 234.72 \\
\hline Others & - & & - & \\
\hline Maize & - & 98.65 & - & 106.89 \\
\hline Paddy & 586.3 & - & 597.6 & - \\
\hline Fodder & 22 & 32.65 & 20 & 36.30 \\
\hline
\end{tabular}


Table.2 Properties of soils in the study area

\begin{tabular}{|c|c|c|c|}
\hline Sr. No. & \multicolumn{2}{|c|}{ Soil Properties } & Details \\
\hline 1. & $\begin{array}{l}\text { Physical } \\
\text { properties }\end{array}$ & $\begin{array}{l}\text { Soil Type } \\
\text { Surface colour } \\
\text { Depth of the soil }\end{array}$ & $\begin{array}{l}\text { Medium black to loamy sand (Goradu) soils } \\
\text { Reddish brown to insity soil of East dark Brown to } \\
\text { dark yellowish brown and grey in alluvial. } \\
0 \text { to } 25 \mathrm{~cm} \text { in hilly area and } 90 \text { to } 180 \mathrm{~cm} \text { in other areas }\end{array}$ \\
\hline 2. & $\begin{array}{l}\text { Chemical } \\
\text { properties }\end{array}$ & $\begin{array}{l}\mathrm{EC}(\text { micromhos } / \mathrm{cm}) \\
\mathrm{pH} \\
\mathrm{N} \\
\mathrm{P} \\
\mathrm{K}\end{array}$ & $\begin{array}{l}\text { More than } 10 \text { in most of the area. } \\
7.9-8.2 \\
\text { Low } \\
\text { Medium } \\
\text { High }\end{array}$ \\
\hline
\end{tabular}

Table.3 Irrigation details of 23/R distributary

\begin{tabular}{|c|c|c|c|c|}
\hline Name of Canal & $\begin{array}{c}\text { Off taking of Panam } \\
\text { main canal }(\mathbf{m})\end{array}$ & Length (m) & $\begin{array}{c}\text { Discharge } \\
\text { (cu-f/s) }\end{array}$ & $\begin{array}{c}\text { Cultural } \\
\text { Command Area } \\
\text { (ha) }\end{array}$ \\
\hline 23/R distributary & 38300 & 7000 & 65 & 2070 \\
\hline
\end{tabular}

Table.4 Crop area constraints of 23/R distributary under existing canal running days at full supply

\begin{tabular}{|c|c|c|}
\hline Season & Crop & Farmer's Affinity \\
\hline Rabi & Wheat & Greater than $50 \%$ of CCA \\
\hline Rabi & Maize & Greater than $20 \%$ of CCA \\
\hline Rabi & Fodder & Greater than $10 \%$ of CCA \\
\hline Rabi & Other & Greater than $0 \%$ of CCA \\
\hline Kharif & Paddy & Greater than $95 \%$ of CCA \\
\hline Kharif & Maize & Less than $5 \%$ of CCA \\
\hline Kharif & Fodder & Less than $5 \%$ of CCA \\
\hline Kharif & Other & Less than $5 \%$ of CCA \\
\hline
\end{tabular}

Table.5 Crop area constraints of 23/R distributary under 60 canal running days at full supply

\begin{tabular}{|c|c|c|}
\hline Season & Crop & Farmer's Affinity \\
\hline Rabi & Wheat & Greater than $30 \%$ of CCA \\
\hline Rabi & Maize & Greater than $20 \%$ of CCA \\
\hline Rabi & Fodder & Greater than $20 \%$ of CCA \\
\hline Rabi & Other & Greater than $0 \%$ of CCA \\
\hline Kharif & Paddy & Greater than $95 \%$ of CCA \\
\hline Kharif & Maize & Less than 5\% of CCA \\
\hline Kharif & Fodder & Less than $5 \%$ of CCA \\
\hline Kharif & Other & Less than $5 \%$ of CCA \\
\hline
\end{tabular}


Table.6 Crop Area Constraints of 23/R Distributary under 90 Canal Running Days at Full Supply

\begin{tabular}{|c|c|c|}
\hline Season & Crop & Farmer's Affinity \\
\hline Rabi & Wheat & Greater than $50 \%$ of CCA \\
\hline Rabi & Maize & Greater than $20 \%$ of CCA \\
\hline Rabi & Fodder & Greater than $10 \%$ \\
\hline Rabi & Other & Greater than $2 \%$ of $\mathrm{CCA}$ \\
\hline Kharif & Paddy & Greater than $95 \%$ of CCA \\
\hline Kharif & Maize & Less than $5 \%$ of CCA \\
\hline Kharif & Fodder & Less than $5 \%$ of CCA \\
\hline Kharif & Other & Less than $5 \%$ of CCA \\
\hline
\end{tabular}

Table.7 Crop Area Constraints of 23/R Distributary under 120 Canal Running Days at Full Supply

\begin{tabular}{|c|c|c|}
\hline Season & Crop & Farmer's Affinity \\
\hline Rabi & Wheat & Greater than $50 \%$ of CCA \\
\hline Rabi & Maize & Greater than $20 \%$ of CCA \\
\hline Rabi & Fodder & more than $10 \%$ of CCA \\
\hline Rabi & Other & more than $0 \%$ of CCA \\
\hline Kharif & Paddy & Greater than $95 \%$ of CCA \\
\hline Kharif & Maize & Less than $5 \%$ of CCA \\
\hline Kharif & Fodder & Less than $5 \%$ of CCA \\
\hline Kharif & Other & Less than $5 \%$ of CCA \\
\hline
\end{tabular}

Table.8 Crop Area Constraints of 23/R Distributary under Existing Canal Running Days at Full Supply with Ground Water

\begin{tabular}{|c|c|c|}
\hline Season & Crop & Farmer's Affinity \\
\hline Rabi & Wheat & Greater than $55 \%$ of CCA \\
\hline Rabi & Maize & Greater than $35 \%$ of CCA \\
\hline Rabi & Fodder & Greater than $10 \%$ of CCA \\
\hline Rabi & Other & Greater than $0 \%$ of CCA \\
\hline Kharif & Paddy & Greater than $95 \%$ of CCA \\
\hline Kharif & Maize & Less than $5 \%$ of CCA \\
\hline Kharif & Fodder & Less than $5 \%$ of CCA \\
\hline Kharif & Other & Less than $5 \%$ of CCA \\
\hline
\end{tabular}


Table.9 Crop Area Constraints of 23/R Distributary under 60 Canal Running Days at Full Supply with Ground Water

\begin{tabular}{|c|c|c|}
\hline Season & Crop & Farmer's Affinity \\
\hline Rabi & Wheat & Greater than $45 \%$ of CCA \\
\hline Rabi & Maize & Greater than $20 \%$ of CCA \\
\hline Rabi & Fodder & Greater than $10 \%$ of CCA \\
\hline Rabi & Other & Greater than $0 \%$ of CCA \\
\hline Kharif & Paddy & Greater than $95 \%$ of CCA \\
\hline Kharif & Maize & Less than $5 \%$ of CCA \\
\hline Kharif & Fodder & Less than $5 \%$ of CCA \\
\hline Kharif & Other & Less than $5 \%$ of CCA \\
\hline
\end{tabular}

Table.10 Crop Area Constraints of 23/R Distributary under 90 Canal Running Days at Full Supply with Ground Water

\begin{tabular}{|c|c|c|}
\hline Season & Crop & Farmer's Affinity \\
\hline Rabi & Wheat & $\begin{array}{c}\text { Greater than } 55 \% \text { of CCA } \\
\text { Greater than } 30 \% \text { of CCA }\end{array}$ \\
\hline Rabi & Maize & Greater than $15 \%$ \\
\hline Rabi & Fodder & Greater than $0 \%$ of CCA \\
\hline Rabi & Other & Greater than $95 \%$ of CCA \\
\hline Kharif & Paddy & Less than $5 \%$ of CCA \\
\hline Kharif & Maize & Less than $5 \%$ of CCA \\
\hline Kharif & Fodder & Less than $5 \%$ of CCA \\
\hline Kharif & Other & \\
\hline
\end{tabular}

Table.11 Crop Area Constraints of 23/R Distributary under 120 Canal Running Days at Full Supply with Ground Water

\begin{tabular}{|c|c|c|}
\hline Season & Crop & Farmer's Affinity \\
\hline Rabi & Wheat & Greater than $55 \%$ of CCA \\
\hline Rabi & Maize & Greater than $30 \%$ of CCA \\
\hline Rabi & Fodder & Greater than $15 \%$ of CCA \\
\hline Rabi & Other & Greater than $0 \%$ of CCA \\
\hline Kharif & Paddy & Greater than $95 \%$ of CCA \\
\hline Kharif & Maize & Less than $5 \%$ of CCA \\
\hline Kharif & Fodder & Less than $5 \%$ of CCA \\
\hline Kharif & Other & Less than $5 \%$ of CCA \\
\hline
\end{tabular}


Table.12 Running Days with Break Period of 23-R Distributary for Year 2015-16

\begin{tabular}{|c|c|c|}
\hline SI. No. & Running Periods (days) & Break Period (days) \\
\hline $\mathbf{1}$ & $10 / 07 / 2015-26 / 07 / 2015(17$ days $)$ & $27 / 07 / 2015-11 / 08 / 2015(16$ days $)$ \\
\hline $\mathbf{2}$ & $12 / 08 / 2015-20 / 08 / 2015(9$ days $)$ & $21 / 08 / 2015-27 / 08 / 2015(7$ days $)$ \\
\hline $\mathbf{3}$ & $28 / 08 / 2015-4 / 09 / 2015(8$ days $)$ & $05 / 09 / 2015-06 / 09 / 2015(2$ days $)$ \\
\hline $\mathbf{4}$ & $7 / 09 / 2015-12 / 09 / 2015(6$ days $)$ & $13 / 09 / 2015-08 / 10 / 2015(26$ days $)$ \\
\hline $\mathbf{5}$ & $9 / 10 / 2015-21-10-2015(13$ days $)$ & $22 / 10 / 2015-1 / 12 / 2015(41$ days $)$ \\
\hline $\mathbf{6}$ & $2 / 12 / 2015-16 / 12 / 2015(15$ days $)$ & $17 / 12 / 2015-30 / 12 / 2015(14$ days $)$ \\
\hline $\mathbf{7}$ & $31 / 12 / 2015(1$ day $)$ & $1 / 1 / 2016-3 / 1 / 2016(3$ days $)$ \\
\hline $\mathbf{8}$ & $4 / 1 / 2016-15 / 1 / 2016(12$ days $)$ & $16 / 1 / 2016-19 / 1 / 2016(4$ days $)$ \\
\hline $\mathbf{9}$ & $20 / 01 / 2016-27 / 01 / 2016(8$ days $)$ & $28 / 01 / 2016-01 / 02 / 2016(5$ days $)$ \\
\hline $\mathbf{1 0}$ & $02 / 02 / 2016-16 / 02 / 2016(15$ days $)$ & $17 / 02 / 2016-20 / 02 / 2016(4$ days $)$ \\
\hline $\mathbf{1 2}$ & $21 / 02 / 2016-29 / 02 / 2016(9$ days $)$ & $1 / 03 / 2016-02 / 03 / 2016(2$ days $)$ \\
\hline $\mathbf{1 3}$ & $03 / 03 / 2016-14 / 03 / 2016(12$ days $)$ & $15 / 03 / 2016-18 / 03 / 2016(4$ days $)$ \\
\hline $\mathbf{1 4}$ & $19 / 03 / 2016-22 / 03 / 2016(4$ days $)$ & $23 / 03 / 2016-25 / 03 / 2016(3$ days $)$ \\
\hline Total & $26 / 03 / 2016-1 / 04 / 2016(8$ days $)$ & - \\
\hline & 137 days & 131 days \\
\hline
\end{tabular}

Fig.1 Location Map of Study Area

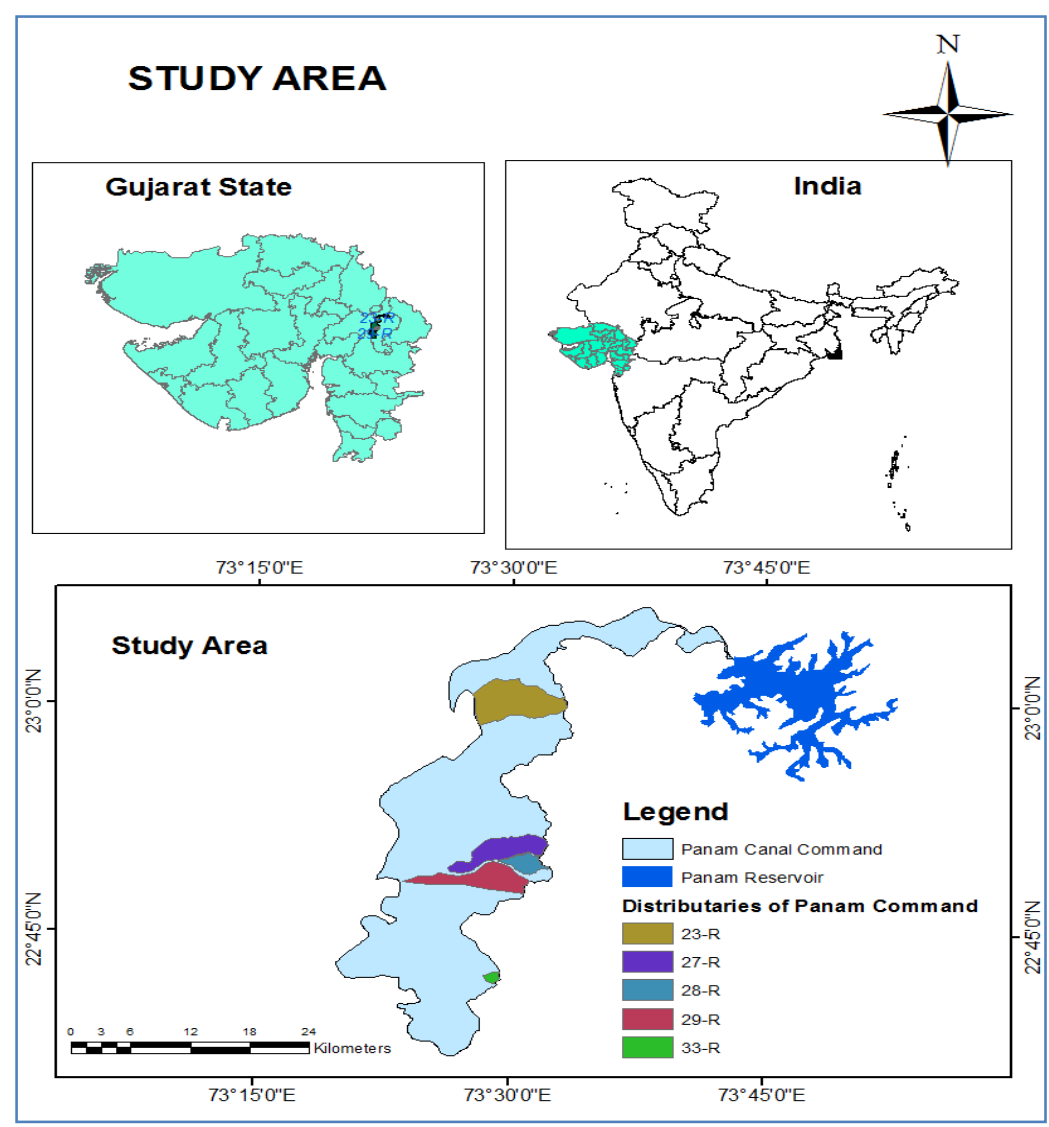


Fig.2 Farmer's Affinity Survey towards crops grown in canal command Area

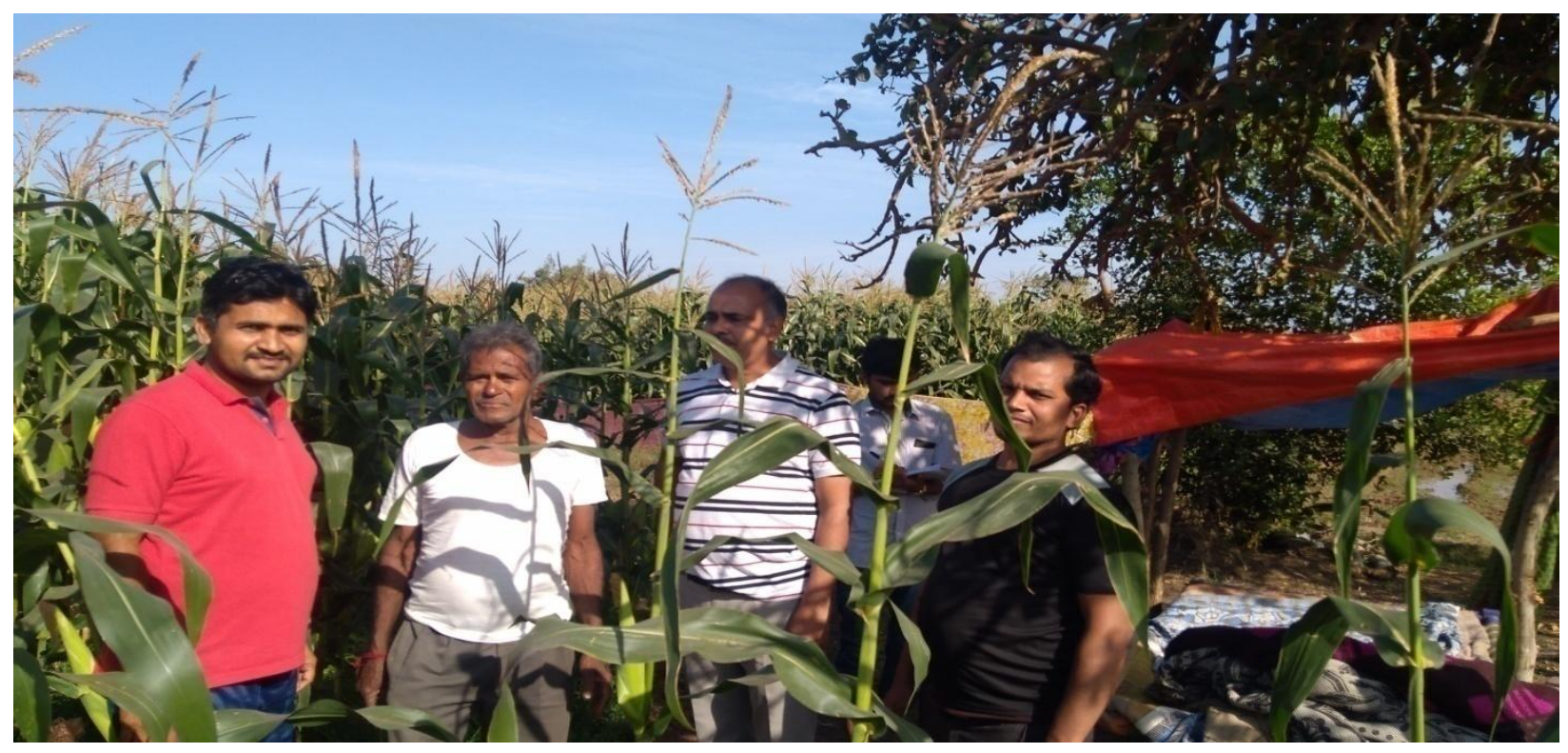

Fig.3 Existing Cropping Pattern in the Command Area of 23-R Distributary

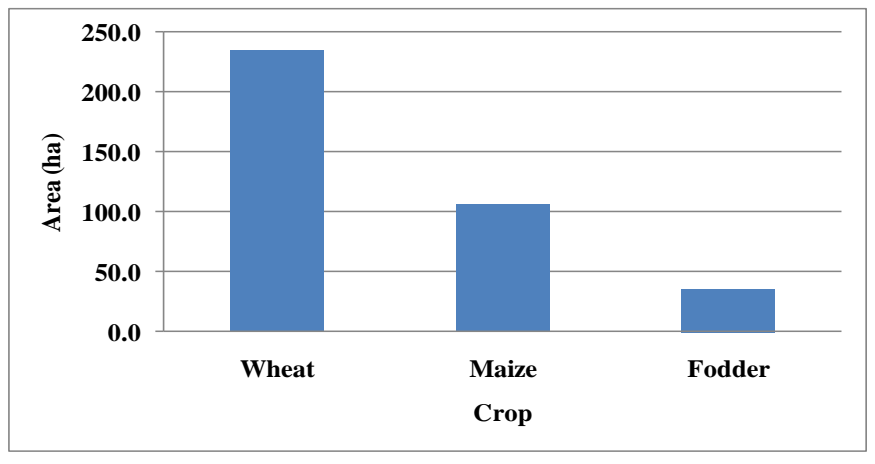

Fig.4 Optimized Cropping Pattern in the Command Area of 23-R Distributary under Existing Canal Running Days at Design Supply Rate

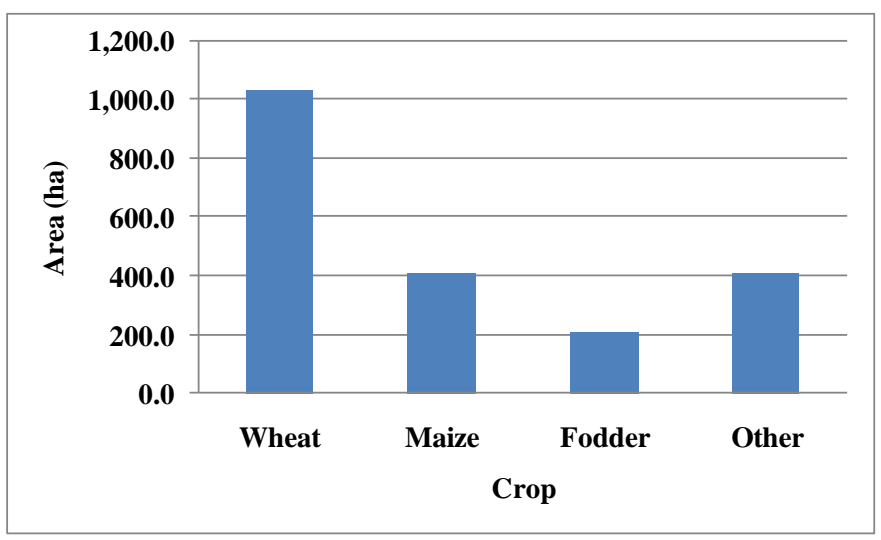


Comparison of net benefit under different optimization approaches with existing situation

Comparison of optimal solution with net profit maximization under different sets of constraints and existing cropping pattern of 23-R distributary is shown in Fig. 12. From Fig. 12, in case of wheat, the maximum net profit of Rs. 184.72 lakh was found in case of 137 days canal supply at design rate with ground water, 90 days canal supply at design rate with ground water and 120 days canal supply at design rate with ground water which is 4.8 times of net profit of existing supply conditions. In case of Maize, the maximum net profit of Rs. 314.65 lakh was found in case of 90 days canal supply at design rate, existing canal supply at design rate with ground water which is 6.7 times of net profit of existing supply conditions. In case of Fodder, the maximum net profit of Rs. 62.69 lakh was found in case of 60 days canal supply at design rate, which is 11.7 times of net profit of existing supply conditions. In case of other, the maximum net profit of Rs. 251. 67 lakh was found in case of existing canal running days at design rate and 120 canal running days at design rate. In present study, there was no other crop in this command area.

It is concluded that in command area of 23-R distributary, in case of wheat, the maximum net profit of Rs. 184.72 lakh was found in case of 137 days canal supply at design rate with ground water, 90 days canal supply at design rate with ground water and 120 days canal supply at design rate with ground water which is 4.8 times of net profit of existing supply conditions. In case of Maize, the maximum net profit of Rs. 314.65 lakh was found in case of 90 days canal supply at design rate, existing canal supply at design rate with ground water which is 6.7 times of net profit of existing supply conditions. In case of Fodder, the maximum net profit of Rs. 62.69 lakh was found in case of 60 days canal supply at design rate, which is 11.7 times of net profit of existing supply conditions. In case of other, the maximum net profit of Rs. 251. 67 lakh was found in case of existing canal running days at design rate and 120 canal running days at design rate. In present study, there was no other crop in this command area. Results show that the developed model is capable to satisfy the demand of command area population.

Application of Research: Optimization modelling of conjunctive use of the irrigation water resources for agricultural sustainability in selected Panam canal command situated in Middle Gujarat.

\section{Acknowledgement/Funding}

Author thankful to Department of Irrigation and Drainage Engineering, College of Agricultural Engineering and Technology, Anand Agricultural University, Godhra, 389001, Gujarat, India.

\section{References}

1.Birajdar, S. A., Nimbalkar, P. T., Sawant, Y. R. and Pawar, P. D. (2016) Estimation of seepage loss from canal by inflow-outflow method \& comparative study of canal lining materials (A case study of NLBC, Malegaon, Tal-Baramati). International Journal of Research in Advanced Engineering and Technology 2(3): 102107.

2.Subramanya, K. (2009) Engineering Hydrology, Third edition, The McGraw-Hill Companies, New Delhi.

3.Kim, S., Kim, B. S., Jun, H., Kim, H. S. (2014) Assessment of future water resources and water scarcity considering the factors of climate change and social- 
environmental change in Han river basin, Korea, Stochastic Environmental Research and Risk Assessment. 28:1999-2014.

4.Guo, P., Chen, X., Li, M. and Li, J. (2014) Fuzzy chance-constrained linear fractional programming approach for optimal water allocation. Stochastic Environmental Research and Risk Assessment. 28: 1601-1612.

5.Singh, A., Panda SN (2012) Development and application of an optimization model for the maximization of net agricultural return. Journal of Agricultural Water Management, 115: 267-275.

6.Allen, R. G., Pereira, L. S., Raes, D. and Smith, M. (1998). Crop Evapotranspiration: Guidelines for computing crop water requirements. Irrigation and Drainage Paper 56, FAO of the United Nations, Rome. 300 pp.

7.Hargreaves, G. H. and Samani, Z. A. (1985) Reference evapotranspiration from temperature. American Society of Agricultural Engineers 1(2): 96-99.

8.Dastane, N. G. (1978) Effective rainfall in irrigated agriculture. Irrigation and drainage paper. 25, FAO, Rome, Italy, p 62.

9.Singh, A. (2012b) Development and application of a watertable model for the assessment of waterlogging in irrigated semi-arid regions. Water Resource Management 26(15): 44354448.

\section{How to cite this article:}

Deepak Kumar and Tiwari, M. K. 2020. Optimization Modelling of Conjunctive Use of the Irrigation Water Resources for Agricultural Sustainability. Int.J.Curr.Microbiol.App.Sci. 9(05): 1467-1480. doi: https://doi.org/10.20546/ijcmas.2020.905.167 